\title{
The mechanism of attracting investments in modernization of public utility facilities
}

\author{
Vyacheslav Teplyshev ${ }^{1,}$, , Rima Petrosyan $^{2}$, Dmitriy Spitsov ${ }^{3}$, Vitaly Smirnov ${ }^{1}$ and Maria \\ Pushkareva $^{1}$ \\ ${ }^{1}$ Moscow Aviation Institute, Volokolamskoe highway, 4, 125993, Moscow, Russia \\ ${ }^{2}$ Moscow State University of Civil Engineering, Yaroslavskoe sh., 26, 129337, Moscow, Russia \\ ${ }^{3}$ Moscow Institute of Architecture, Rozhdestvenka street 11, 107031, Moscow, Russia
}

\begin{abstract}
The purpose of the study is to develop theoretical provisions and practical tools for attracting investment resources for the renewal of the fixed assets of the housing and communal services enterprises (hereinafter Housing and Communal Services). In the article the condition and reveals, the trends in the development of the housing and communal services have been analyzed, the forms and methods of the attracting investment resources have been explored, a model for identifying the most priority projects for the reconstruction and renovation of the communal infrastructure have been formed, a mechanism for searching for and attracting extra-budgetary sources of the investment has been developed, and an algorithm for monitoring the effectiveness of the using extrabudgetary sources of the investment has been formed. The research was carried out using a system approach, economic and mathematical modeling, general scientific methods, methods and statistical analysis. The processing of the information obtained through analysis and modeling was carried out using modern methods that support collection procedures.
\end{abstract}

\section{Introduction}

Housing and communal services are a vitally important branch of the national economy that ensures the functioning of the engineering infrastructure of the various buildings of the settlements, creating convenience and comfort of the living and finding citizens in them by providing them with a wide range of the housing and communal services.

Speaking at the initial stage of the economic reforms in the role of the shock absorber of the social consequences of the price liberalization, the housing and communal services in the region turns into a source of the threats to the country social and economic development. The degradation of the housing and communal services of the individual regions has come to the brink of the irreversible processes, when the possibility of the losing control in this important sphere of the life support for people, the whole society, is possible on any day. The population of the regions expects effective steps from the state to take the industry out of the crisis, including on the basis of the improving the mechanism for investment support for the renovation of the infrastructure of the housing and communal

*Corresponding author: teplyshev@tbnenergo.com 
services [1]. The volume of the housing and communal services produced increases year by year. The share of the housing and communal services in the gross domestic product in Russia as a whole in 2010 was 8.3 percent. In addition, in the sphere of the housing and communal services, a significant number of the enterprises of the various forms of the ownership function, including: private, joint-stock, departmental and others. The significant part in the structure of the provision of the public services is occupied by energy and gas supply companies.

\section{Materials and methods}

In the communal services, the following trends are observed: the volume of the production of the services is increasing due to the transfer of the housing and communal services of the region from departments (factories, military units, etc.) to the ownership of the region; increase in prices and tariffs for utility services (both because of the rising costs of energy resources, and increased losses in networks when operating worn and inefficient equipment). The reverse trend is observed in the water sector: the volume of the wastewater and water discharge has been reduced, which is due to technical limitations on throughput and the lack of the construction of new engineering structures. In turn, the increase in the amount of the heat supply is explained by a significant increase in the consumption of the heat energy by industrial enterprises, the consumption of the heat energy by the population is reduced, which is due to almost constant underheating of the coolant to the established standards. The lack of the budgetary funds to ensure the activities of the housing and communal services in the region leads to the deterioration of the infrastructure of the housing and communal services, increases the loss of the resources in the production and transportation process, which, on the one hand, requires the speedy implementation of the investment measures related to overcoming this problem, on the other hand, use of the investment support [2]. The analysis of the state of the housing and communal services in the region made it possible to identify the problems typical for the industry, the classification of which is presented in figure 1 .

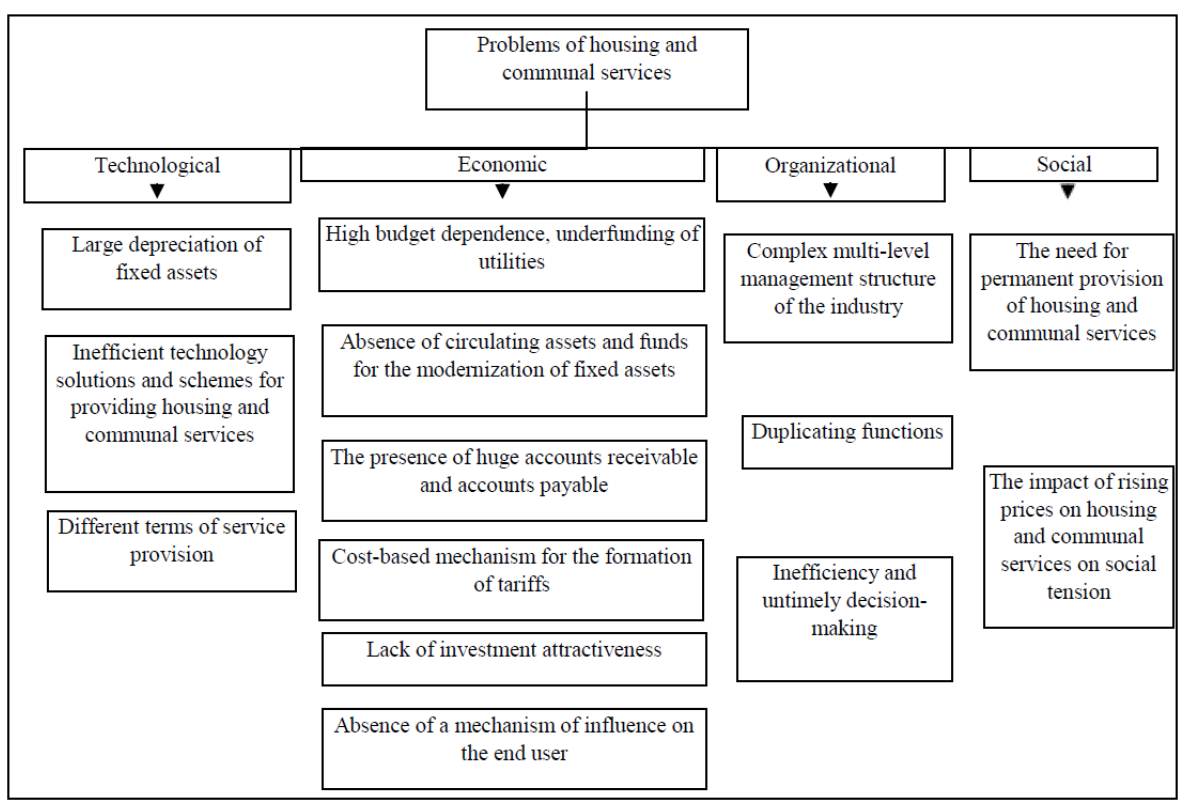

Fig. 1. Analysis of the state of the housing and communal services. 
It is advisable to develop a program for the restoration and modernization of the fixed assets of the housing and utilities enterprises, taking into account the following conceptual provisions for the prospective attraction of the private investment sources:

- selection of the activities for investment activities of the enterprises;

- complex examination of the applications for investment;

- funding of the events;

- ensuring return on investment;

- monitoring of the implementation of the activities;

- risk management.

Housing is a part of the economy of the region, designed to serve the needs of a person in housing. The housing of the region is of the great social importance, since housing, along with food, is the basis of the human existence. The composition of the housing sector in the region includes:

- Housing stock;

- Housing-operational enterprises and organizations, repair and construction enterprises and organizations that specialize in capital repair of the housing stock;

- specialized repair and construction and repair and maintenance organizations focused on repair and maintenance of engineering equipment of the houses;

-Management of the mechanization and special motor vehicle, providing housing organizations with emergency and other special transport, harvesting, construction equipment and machinery;

- units carrying out material and technical support of the enterprises and organizations of the housing;

-industrial enterprises that manufacture products for the needs of the housingoperational organizations;

-Scientific, educational organizations that provide scientific services, training and professional development of the housing specialists;

- Settlement-cash and computing centers for collective use, etc.

The municipal economy is an important part of the regional infrastructure, which forms (together with the housing economy) the person's living environment [3]. The structure of the municipal economy of the region includes the following sub-sectors:

- Resource supply (heat, electricity, gas, water and sanitation);

- improvement (road and bridge economy, gardening, bank protection, sanitation, waste disposal);

-habitual service (bath-housekeeping, hotel industry, ritual services).

Methods and forms of the attracting investment resources are presented in figure 2.

Examination of the existing forms and methods of the investment provision of the housing and communal services has shown that mechanisms of the participation of the state and municipalities in attracting private long-term borrowed resources are currently ineffective, that is, existing mechanisms are still focused mainly on attracting budgetary funds. The allocation of a function to provide funding on a return basis on market conditions creates the prerequisites for replacing budget return financing for attracting private credit investments, at the first stage - under the guarantee of the budgets, as well as specially created guarantee structures [4].

To ensure the possibility of the attracting the funds of the commercial banks or housing project bonds for financing housing and utilities infrastructure modernization projects, specialized guarantee agencies with state participation (hereinafter referred to as SGA) may be established. The main function of MHA should be issuing guarantees on loans from commercial banks for the implementation of approved MGA projects, which will take advantage of the financial leverage. The ultimate goal of the activities of such guarantee 
structures should be to reduce the cost of the credit and other borrowed resources secured by the guarantee of the MGA

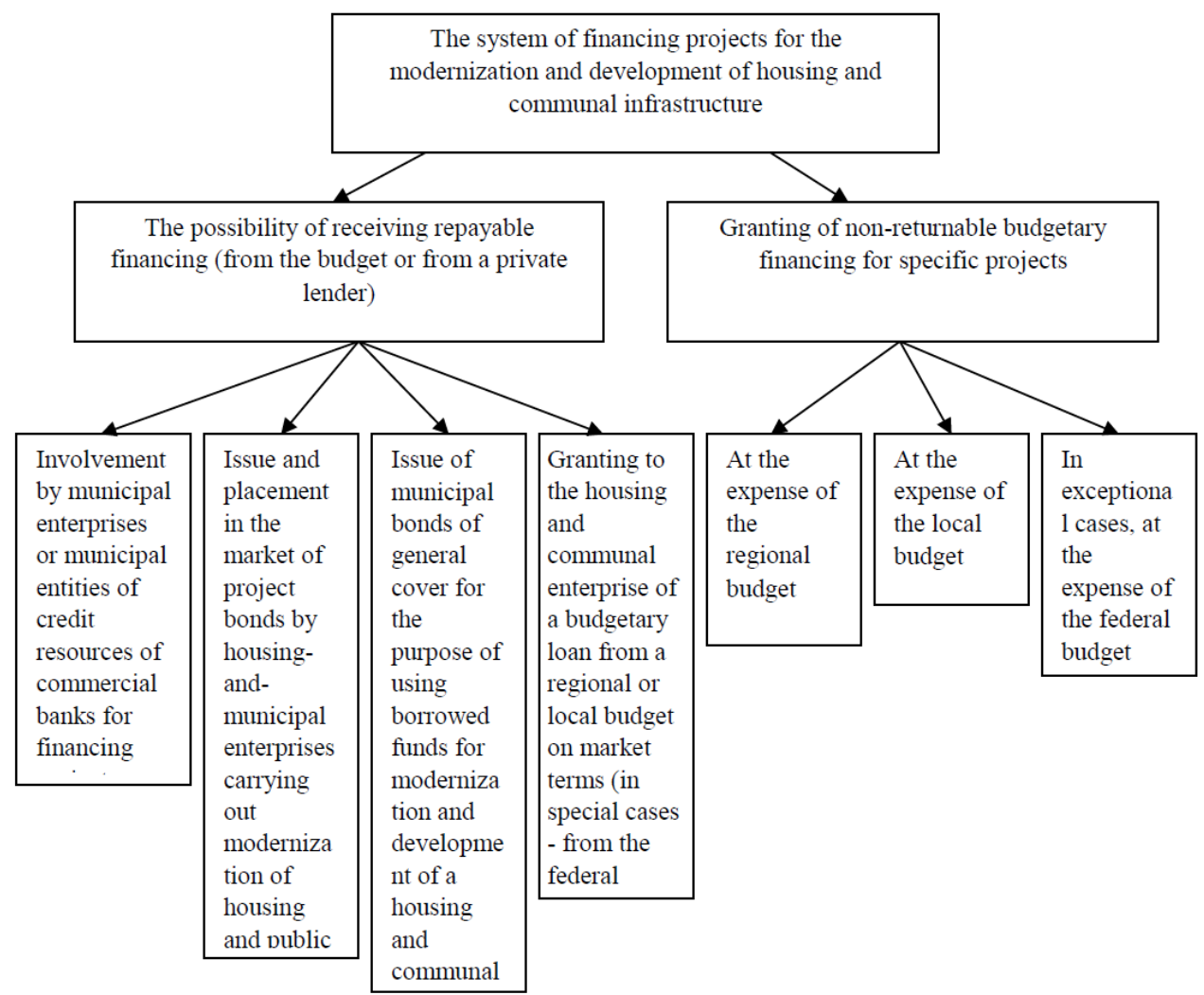

Fig. 2. Mechanisms for the participation of the state and municipalities in attracting private long-term borrowed funds to utilities.

\section{Results}

A comparative analysis of the investment attractiveness of the infrastructure objects of the housing and communal services in the region made it possible to divide them into groups with high, medium and low investment attractiveness on the basis of the level of the investment attractiveness.

A high degree of the investment attractiveness is characterized by:

- regional housing stock and non-residential premises;

- The property of the regional housing and communal services, transferred to economic management, operational management, rent, free use, trust management;

- land and other natural resources owned by enterprises of the housing and communal services in the region.

The average investment attractiveness is enjoyed by:

- enterprises, organizations and institutions of the housing and communal services in the region;

- property assigned to the right of the operational management and gratuitous use for enterprises of the housing and communal services of the region; 
- property created or purchased by enterprises of the housing and communal services of the region at their own expense or received free of the charge.

Low investment attractiveness is enjoyed by:

- shares (units) of the property deposits in enterprises of the various forms of the ownership, shares of the joint-stock companies, other securities owned by the housing and communal services of the region;

- objects of the intellectual property; other movable and immovable property of the enterprises of the housing and communal services of the region;

- infrastructure of the housing and communal services in the region.

Thus, it follows from the presented classification that the modernization of the property complexes of the housing and communal services enterprises has low investment attractiveness, primarily for private capital.

The mechanism for attracting investment resources for projects for the restoration of the fixed assets of the utilities is shown in Fig. As can be seen from the figure, it is proposed to assess the development of the housing and communal services in the region, taking into account the analysis of the programs and the legislative framework for the development of the housing and communal services in the region [5].

At the same time capital assets pricing model (CAPM) for objects housing and utility sector infrastructure of the region is developed for the estimation of the objects' competitiveness of the housing and utility sector enterprises property complexes. Considering this model, the objects' of the housing and utility sector enterprises property complexes inversion, ranked according to the levels of the investment attractiveness, is done if only to close the most problematic industry positions.

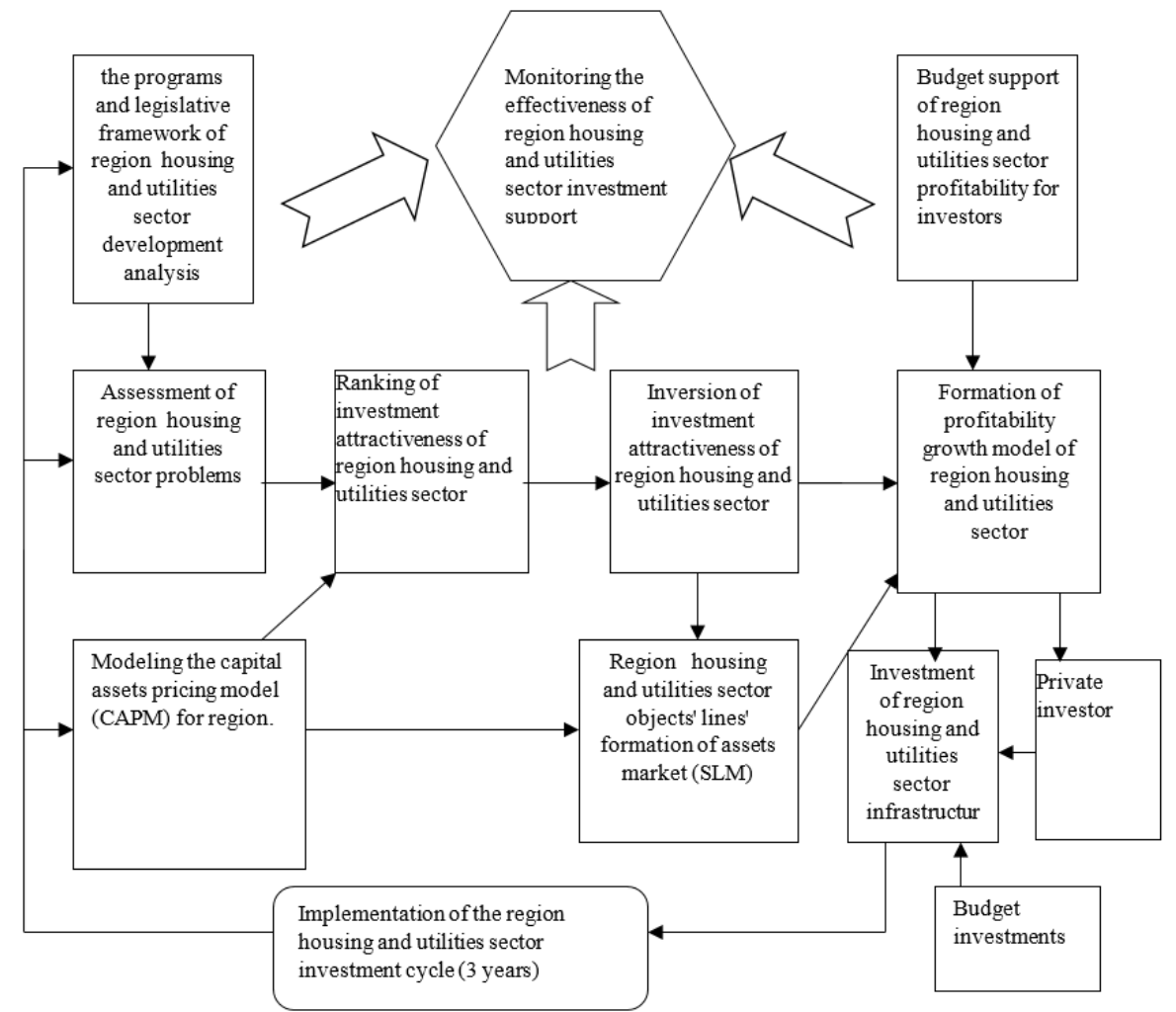

Fig. 3. The attracting investment resources in rehabilitation and upgrading projects of the fixed assets mechanism. 
There are four target indicators used to assess the state program effectiveness of the communal infrastructure facilities modernization (table 1)

Table 1. Target indicators assessing the state programs' effectiveness of the communal infrastructure facilities modernization.

\begin{tabular}{|c|c|c|c|c|}
\hline No & Indicator & Given data & Sources & Calculation algorithm \\
\hline 1 & $\begin{array}{l}\text { Deterioration level of } \\
\text { communal } \\
\text { infrastructure }\end{array}$ & $\begin{array}{l}\text { Data for } \\
\text { deterioration level of } \\
\text { communal } \\
\text { infrastructure }\end{array}$ & $\begin{array}{l}\text { Territorial body of } \\
\text { Federal state } \\
\text { statistics service }\end{array}$ & $\begin{array}{l}\text { Average values' calculation of } \\
\text { deterioration level of } \\
\text { communal infrastructure by } \\
\text { groups }\end{array}$ \\
\hline 2 & $\begin{array}{l}\text { An extra-budgetary } \\
\text { sources' fraction in } \\
\text { cumulative } \\
\text { investment in the } \\
\text { modernization of } \\
\text { municipal } \\
\text { infrastructure }\end{array}$ & $\begin{array}{l}\text { An extra-budgetary } \\
\text { sources' volume in } \\
\text { the modernization of } \\
\text { municipal } \\
\text { infrastructure }\end{array}$ & $\begin{array}{l}\text { The department of } \\
\text { region housing } \\
\text { and utility sector } \\
\text { and infrastructure } \\
\text { monitoring } \\
\text { results. }\end{array}$ & $\begin{array}{l}\text { Volume relation of an extra- } \\
\text { budgetary sources' volume in } \\
\text { region municipal } \\
\text { infrastructure modernization, } \\
\text { to the total investment in } \\
\text { region communal } \\
\text { infrastructure modernization. }\end{array}$ \\
\hline 3 & $\begin{array}{l}\text { A share of private } \\
\text { companies managing } \\
\text { public infrastructure } \\
\text { facilities on the basis } \\
\text { of concession } \\
\text { agreement and other } \\
\text { contracts. }\end{array}$ & $\begin{array}{l}\text { A share of private } \\
\text { companies managing } \\
\text { communal } \\
\text { infrastructure } \\
\text { facilities on the basis } \\
\text { of concession } \\
\text { agreement and other } \\
\text { contracts. Total } \\
\text { number of all } \\
\text { utilities complex } \\
\text { organizations of the } \\
\text { region. }\end{array}$ & $\begin{array}{l}\text { The department of } \\
\text { region housing } \\
\text { and utility sector } \\
\text { and infrastructure } \\
\text { monitoring } \\
\text { results. }\end{array}$ & $\begin{array}{l}\text { Volume relation of private } \\
\text { companies managing } \\
\text { communal infrastructure } \\
\text { facilities on the basis of } \\
\text { concession agreement and } \\
\text { other contracts, to the total } \\
\text { number of all utilities } \\
\text { complex organizations, } \\
\text { operating in the region. }\end{array}$ \\
\hline 4 & $\begin{array}{l}\text { The overdue creditor } \\
\text { indebtedness volume } \\
\text { of housing and utility } \\
\text { sector enterprises }\end{array}$ & $\begin{array}{l}\text { The overdue creditor } \\
\text { indebtedness of } \\
\text { housing and utility } \\
\text { sector enterprises }\end{array}$ & $\begin{array}{l}\text { The department of } \\
\text { region housing } \\
\text { and utility sector } \\
\text { and infrastructure } \\
\text { monitoring } \\
\text { results. }\end{array}$ & $\begin{array}{l}\text { The data summing-up of } \\
\text { overdue creditor indebtedness } \\
\text { of housing and utility sector } \\
\text { enterprises at year-end }\end{array}$ \\
\hline
\end{tabular}

The evaluation principle for any of the presented target indicators is the same and involves comparing an actual and a target indicator level at year-end [6].

The Analytically generalized criterion evaluation of the regional program communal infrastructure facilities modernization effectiveness Q, can be written in the form:

$$
\mathrm{Q}=\mathrm{I}_{1}+\mathrm{I}_{2}+\mathrm{I}_{3}+\mathrm{I}_{4}
$$

where $\mathrm{I}_{1}$ - relative value meangroup level of communal infrastructure wear and tear:

$$
I_{1}=\frac{F_{b}}{F_{f}}
$$

where $\mathrm{F}_{\mathrm{b}}$ - target level of the communal infrastructure wear and tear;

$\mathrm{F}_{\mathrm{f}}$ - actual level of the communal infrastructure wear and tear;

$\mathrm{I}_{2}$ - relative share of the extra-budgetary sources in cumulative investment volume in the communal infrastructure modernization:

$$
I_{2}=\frac{G_{f}}{G_{b}}
$$

where $G_{f}-$ actual share of the extra-budgetary sources in cumulative investment volume in the communal infrastructure modernization; 
$\mathrm{G}_{\mathrm{b}}$ - required share of the extra-budgetary sources in cumulative investment volume in the communal infrastructure modernization;

$\mathrm{I}_{3}$ - relative share of the private companies managing communal infrastructure facilities on the basis of the concession agreement and other contracts:

$$
I_{3}=\frac{H_{f}}{H_{b}}
$$

where $\mathrm{H}_{\mathrm{f}}$ - actual share of the private companies managing communal infrastructure facilities on the basis of the concession agreement and other contracts;

$\mathrm{H}_{b}$ - required share of the private companies managing communal infrastructure facilities on the basis of the concession agreement and other contracts;

$\mathrm{I}_{4}$ - relative contraction of the overdue creditor indebtedness volume of the housing and utility sector enterprises:

$$
I_{4}=\frac{\Delta K_{f}}{\Delta K_{b}}
$$

where $\Delta K_{f}-$ actual contraction of the overdue creditor indebtedness volume of the housing and utility sector enterprises in a year;

$\Delta \mathrm{K}_{\mathrm{b}}$ - required contraction of the overdue creditor indebtedness volume of the housing and utility sector enterprises in a year.

Thus, the basic level of the generalized criterion evaluation of the communal infrastructure facilities modernization effectiveness $Q$ is the 4 value, which means that each of the indicators $I_{1}, I_{2}, I_{3}, I_{4}$ are equal to one. In addition to the above, indicator $I_{4}$ may have a negative value, which means a creditor indebtedness increase.

The disadvantage of the generalized criterion evaluation of the communal infrastructure facilities modernization effectiveness $Q$ is the infrastructure innovation development accounting lack. That's why relative level of the communal infrastructure innovation development $I_{5}$ is suggested to be added in the target indicator system of the regional programs' effectiveness evaluation of the communal infrastructure facilities modernization:

$$
I_{5}=\frac{I_{f}}{I_{b}}
$$

where $I_{f}$ - actual level of the communal infrastructure innovation development;

$\mathrm{I}_{\mathrm{b}}$ - basic level of the communal infrastructure innovation development.

Thus, generalized criterion evaluation of the regional program communal infrastructure facilities modernization effectiveness $\mathrm{Q}$, is converted to:

$$
\mathrm{Q}=\mathrm{I}_{1}+\mathrm{I}_{2}+\mathrm{I}_{3}+\mathrm{I}_{4}+\mathrm{I}_{5}
$$

Effectiveness monitoring of the innovative support holds a valuable place in the question of the project effectiveness of the region housing and utility sector reconstruction and modernization [7].

Monitoring is a constant, systematic, detailed, current monitoring of the the basic funds state of the region housing and utility sector enterprises. Monitoring organization algorithm is the following:

- expert kick-off structuring: establishment of the logical, cause-and-effect and other relationships between different spheres of the housing and utility sector enterprises activity within the framework of the investment support.;

- defining the monitoring aim: the purpose of the carrying monitoring may vary within sizeable limits: from violations detection in individual operation implementation to 
identify changes in the participants' of the investment support process preferences and the signs of the crisis occurrence;

- constant exponents (indicators) choice: balanced exponents system is applied as indicator for each group of the investment support process participants;

- data collection: an existence of the designed database in the enterprise, which fundamentally would be an enterprise activity model, is necessary for obtaining an adequate information;

- preliminary formalization of the analytical materials: presentation on paper or computer of the given data, which is necessary for the indicators calculation, selected in accordance with the set aim at early stages of the monitoring process preparation planning;

- hierarchical ordering, filtering and data reduction, graphical visualization of the data: definition of the indicators values at the current time, the results interpreting in relation to each of the housing and utility sector enterprises activity spheres, presentation of the results in a visual form;

- conformity detection and stable trends: it is necessary to conduct a retrospective analysis of the selected indicators, and also to present in a formalized form the causeand-effect and other relationships, identified by experts at an early stage of the monitoring process.

Monitoring effectiveness of the housing and utility sector enterprise investment support algorithm is represented in the figure 4.

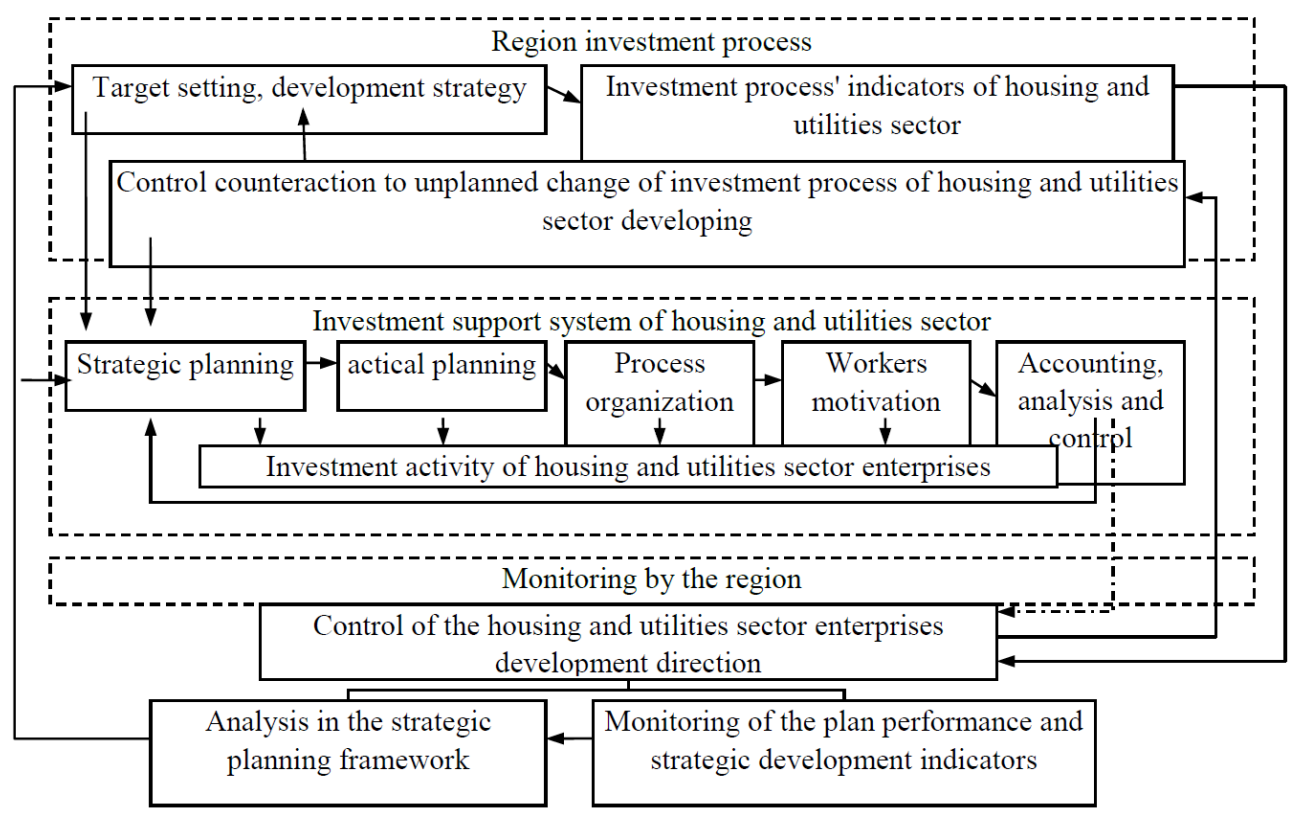

Fig. 4. Monitoring effectiveness of the housing and utility sector enterprise investment support.

A constant, systematic, detailed, current monitoring of the basic funds state of the region housing and utility sector enterprises, that is monitoring, provides formation of the necessary database for strategic enterprises action planning. Monitoring should be continuous and its results should have an impact on managerial decision - making. Only in this case, monitoring transforms into a unique instrument for preparation and grounds of the management decisions [8]. 


\section{Conclusion}

The analysis of the existing forms and methods of the investment resources attracting in the projects of the restoration and modernization of the housing and utility sector enterprises basic funds allowed substantiating the fact that the participation mechanisms of the state and municipalities in attracting private long-run debt resources are currently ineffective. That is, operating mechanisms are still oriented specifically on attracting budget funds. The reason of the current situation is that the objects of the of the region housing and utility sector enterprises asset complex, except of the housing project and uninhabitable commercial real estate, have low investment attractiveness for private capital, have low investment attractiveness for private capital. First of all, it affects the state of the housing and utility sector infrastructure. Thus, it was determined that the priority areas of the housing and utility sector services investment are related to a group of the objects with low investment attractiveness.

\section{References}

1. T. Narezhnaya, L. Prykina, IOP Conference Series: Earth and Environmental Science 19, 90012141 (2017)

2. E. Gurova, T. Larinina, N. Zakorin, L. Andreeva, L. Manukhina, MATEC Web of Conferences, 08085 (2017)

3. L. Manukhina, I. Ivanova, IOP Conference Series: Earth and Environmental Science 19, 90012166 (2017)

4. S.A. Baronin, K.Y. Kulakov, Journal of Applied Economic Sciences 11(4), 698-708 (2016)

5. N. Danilina, E3S Web of Conf. Series: International Conference on Sustainable Cities, ICSC 2016, 02001 (2016)

6. P.G. Grabovy, A.K. Orlov, Procedia Engineering 153, 195-202 (2016)

7. S.A. Baronin, K.Y. Kulakov, Journal of Advanced Research in Law and Economics 6(2), 291-298 (2015)

8. P.G. Grabovyi, I.P. Avilova, Life Science Journal 12, 610-615 (2014) 